\title{
REFORMASI PELAYANAN PUBLIK SEBAGAI STRATEGI MEWUJUDKAN GOOD GOVERNANCE
}

Muhammadiah

Fakultas Ilmu Sosial dan Ilmu Politik Universitas Muhammadiyah Makassar Jl. Sultan Alauddin No. 259 Makassar 90221 Telp. 0411 - 866972 ext. 102 Fax. 0411 - 865588

\section{ABSTRACT}

System of government with good governance paradigm is intended to further promote the involvement of all stakeholders in governance. In practical terms, the challenge of good governance paradigm will be faced with the demands of society in improving the quality of public services. Public service practices that are conducive to stimulating real and public participation to further improve the implementation of good governance. so many public service activities that feel a lack of good public service, so that all parties are less optimistic about the realization of good governance in Indonesia. A country with a high heterogeneity conditions in a variety of things such as ethnic, cultural, geographical, religious, and socio-economic development level, is a considerable potential as a source of conflict, and can lead to national disintegration. Development of civil society requires a public space (public sphere) in which every citizen could freely and independently express opinions about various social problems. Transparency of information and public service is fundamental in the governance demands that the principle of good governance, in which required the disclosure of information as one of the implementation requirements of public accountability.

Keywords: Public services, Good Governance, Transparency

\section{ABSTRAK}

Sistem pemerintahan dengan paradigma pemerintahan yang baik dimaksudkan untuk lebih mempromosikan keterlibatan semua pemangku kepentingan dalam pemerintahan. Dalam istilah praktis, tantangan paradigma pemerintahan yang baik akan dihadapkan dengan tuntutan masyarakat dalam meningkatkan kualitas pelayanan publik. Pelayanan publik praktek-praktek yang kondusif untuk merangsang partisipasi yang nyata dan masyarakat untuk lebih meningkatkan pelaksanaan pemerintahan yang baik. begitu banyak kegiatan pelayanan publik yang merasa kurangnya layanan publik yang baik, sehingga semua pihak yang kurang optimis tentang realisasi pemerintahan yang baik di Indonesia. Sebuah negara dengan kondisi heterogenitas yang tinggi dalam berbagai hal seperti tingkat perkembangan etnis, budaya, geografis, agama, dan sosial-ekonomi, adalah potensi besar sebagai sumber konflik, dan dapat menyebabkan disintegrasi nasional. Pengembangan masyarakat sipil membutuhkan ruang publik (ruang publik) di mana setiap warga negara bisa secara bebas dan mandiri mengekspresikan pendapat tentang berbagai masalah sosial. Transparansi informasi dan pelayanan publik adalah fundamental dalam tuntutan pemerintahan yang prinsip pemerintahan yang baik, di mana diperlukan keterbukaan informasi sebagai salah satu persyaratan pelaksanaan akuntabilitas publik.

Kata Kunci: Pelayanan publik, Good Governance, Transparansi 


\section{A. PENDAHULUAN}

Pelayanan publik yang berkualitas merupakan tuntutan yang sangat mendasar dalam sistem pemerintahan good governance. Pertanyaan yang berkaitan dengan masalah ini, adalah mengapa reformasi pelayanan publik menjadi persoalan strategis untuk membangunan good governance, pada hal sebenarnya masih banyak aspek penting yang juga yang perlu diperhatikan dalam penyelenggaraan good governance. Pemerintah menghadapi menghadapi persoalan yang tidak kalah pentingnya dalam mewujudkan good governance, seperti persoalan membangun karakter bangsa (nation character building), persoalan minyak bumi yang sudah kritis, dan persoalan kehutanan (ilegal loging) yang makin sulit diatasi, dan pencurian ikan yang makin meningkat, penambangan ilegal hasil tambang seperti pasir, batu bara. Pertanyaan ini perlu dijawab agar kita semua memahami mengapa kita memilih membangun pelayanan publik daripada persoalan-persoalan tersebut.

Argumen yang paling kuat kita memilih memprioritaskan membangunan pelayanan publik adalah agar benar-benar diyakini bahwa pelayanan publik yang kondusif dapat mengantar dan menjdikan bangsa Indonesia mampu mewujudkan good governance dalam kehidupan bermasyarakat, berbangsa dan bernegara. Jawaban lainnya adalah bahwa karena reformasi pelayanan publik memiliki dampak yang cukup luas terhadap perubahan perilaku birokrasi dan masyarakat. Diharapkan juga bahwa melalui reformasi pelayanan publik agar tercipta pelayanan publik yang dapat menjadi lokomotif pembangunan menuju good governance.

Dalam kaitan ini, ada beberapa pertimbangan mengapa pelayanan publik menjadi fokus dalam memulai implementasi good governance khususnya di Indonesia. Pertama; bahwa pelayanan publik di Indonesia masih merupakan persoalan krusial, dimana sebagian besar masyarakat merasa bahwa pelayanan publik yang selama ini dilaksanakan masih jauh dari pelayanan publik yang sesungguhnya. Pelayanan publik yang mahal, waktu yang lama, proses yang berbelit-belit, kurangnya akurasi, merupakan sesuatu yang hampir dialami dalam berbagai macam kegiatan pelayanan publik di Indonesia. Kelemahan pelayanan publik yang demikian ini telah menjadikan masyarakat enggan, malas, dan takut berhubungan dengan birokrasi.

Praktek pelayanan publik yang kondusif sesungguhnya dapat membangkitkan semangat dan partisipasi publik untuk lebih meningkatkan penyelenggaraan good governance. Pelayanan publik yang kondusif seharusnya tidak hanya mitos, slogan dan janji, tetapi harus menjadi realitas dalam kehidupan bermasyarakat dan bernegara. Jika saat ini apatisme dan pesimisme masyarakat terhadap eksistensi birokrasi sebagai lembaga pelayanan publik terasa makin luas, terutama disebabkan oleh birokrasi telah lama dan terus mempraktekkan bad governance, seperti pungutan liar yang terjadi pada hampir seluruh birokrasi, keramahan birokrat yang masih sulit didapatkan, prosedur yang berbelit-belit dan waktu yang lama menjadi pengalaman setiap hari bagi mereka yang berhubungan dengan birokrat. Namun sangat ironi, karena masyarakat juga terpaksa mengapresiasi praktek bad governance, karena memudahkan mereka mendapatkan pelayanan publik. Bahkan masyarakat menilai bahwa bad governance, khususnya pungutan liar (pungli) adalah wajar, tidak jadi masalah, justru merasa lega karena proses pelayanan dapat segera selesai (Dwiyanto, 2008). Masyarakat rela membayar mahal yang penting urusan cepat selesai (Kristiadi, 2005).

Praktek bad governance telah merambah ke berbagai level pemerintahan. Bad governance tidak hanya terjadi eselon rendah, tetapi juga pada eselon tinggi, juga tidak hanya terjadi pada pemerintah pusat, tetapi telah sampai ke pemerintah daerah. Bad governance bukan hanya terjadi di lembaga eksekutif, tetapi juga terjadi dilembaga legislatif dan yudikatif. Bad governance bukan hanya terjadi di lembaga pemerintahan, tetapi juga di berbagai Badan Usaha Milik Negara (BUMN) dan Badan Usaha Milik Daerah (BUMD).

Demikian luasnya lembaga yang mempraktekkan bad governance dan begitu banyaknya aktivitas pelayanan publik yang 
merasakan pelayanan publik yang kurang baik, sehingga berbagai pihak masih kurang optimis terhadap terwujudnya good governance di Indonesia. Diakui secara konseptual dan visi dari good governance telah cukup memadai, namun secara misi dan implementasi masih sulit direalisasikan. Kondisi seperti ini menjadikan masyarakat makin toleran terhadap bad governance, sehingga apa yang menjadi harapan dalam good governance masih jauh dari kenyataan. Oleh karena itu, jika kita komitmen kepada good governance, maka kebiasaan-kebiasaan buruk yang terjadi dalam penyelenggaraan pelayanan publik (bad governance) seharusnya harus dieliminer, direduksi, hingga pada gilirannya kita menikmati good governance yang sesungguhnya. Harus ada komitmen yang kuat bahwa nilai-nilai yang terdapat good governance harus diwujudkan dalam perilaku semua pihak, bukan hanya dari birokrasi, tetapi juga dari masyarakat yang memiliki kebiasaan suka menabrak (melanggar) prosedur, tidak senang entry, memaksakan kehendak, mencari jalan pintas, tidak merasa risih dengan perilaku bad governance.

\section{B. GOOD GOVERNANCE SEBAGAI PERADABAN DALAM SISTEM PEMERINTAHAN DAN PELAYANAN PUBLIK}

Sistem pemerintahan sebagai hasil peradaban manusia terus mengalami perkembangan dan kemajuan. Salah satu sistem pemeritahan yang terkenal dan menjadi harapan masyarakat dalam dunia modern adalah Good governance. Good governance sebagai suatu perkembangan peradaban yang luhur dalam bidang sistem pemerintahan, karena hakikat dan tujuannya sejalan dengan tuntutan kehidupan masyarakat. Sistem pemerintahan dengan paradigma good governance dimaksudkan untuk lebih mengedapankan keterlibatan seluruh stakeholders dalam penyelenggaraan pemerintahan. Sistem pemerintahan good governance memberikan ruang bagi masyarakat untuk ikutserta berpartisipasi dalam setiap tahapan dan aktivitas penyelenggaraan pemerintahan.
Keberadaan masyarakat dalam penyelenggaraan sistem pemerintahan good governance merupakan refresentasi bahwa organisasi pemerintahan adalah milik, oleh dan untuk kepentingan masyarakat. Keikutsertaan seluruh lapisan masyarakat dalam penyelenggaraan pemerintahan merupakan bukti pengakuan akan pentingnya peranserta masyarakat dalam mengurus dan mewujudkan tujuan masyarakat. Dalam sistem pemerintahan good governance, masyarakat memiliki peran strategis, karena masyarakat turut menentukan arah, proses dan tujuan sistem pemerintahan. Masyarakat bukan lagi sebagai penonton, tetapi juga telah menjadi pemain sentral sejajar dengan lembagalembaga lain dalam sistem pemerintahan good governance. Sistem pemerintahan good governance sangat mengedepankan keterbukaan, transparansi, kebersamaan dan kesetaraan antara pemerintah dengan masyarakat. Dengan demikian good governance merupakan penjabaran secara eksplisit penyelenggaraan sistem demokratisasi pemerintahan.

Dalam penyelenggaran sistem pemerintahan good governance, masyarakat diharapkan tampil sebagai pelaku atau aktor yang dapat mendorong terciptanya sistem pemerintahan yang sesuai dengan dinamika dan tuntutan masyarakat yakni pelayanan publik yang berkualitas atau pelayanan yang sesuai dengan kebutuhan dan kepentingan masyarakat. Sistem pemerintahan good governance menuntut organisasi publik bertindak sebagai agen perubahan (agent of changes), agen pembaruan (agent of innovation), dan agen pembangunan serta lembaga terdepan yang melayani berbagai kepentingan dan memenuhi harapan masyarakat.

Good governance merupakan sistem ketatapemerintahan yang menjadi harapan besar dari berbagai lapisan masyarakat, karena sistem pemerintahan yang mengembangkan paradigma good governance diharapkan mampu menciptakan pemerintahan yang efisien dan efektif. Frederickson (1997) mengartikulasikan governance sebagai suatu proses dimana suatu sistem sosial, ekonomi atau sistem organisasi kompleks lainnya dikendalikan dan diatur. Sedangkan dalam 
perspektif fungsional, governance dimaknai sebagai praktek penyelenggaraan kekuasaan dan kewenangan oleh pemerintah dalam pengelolaan urusan pemerintahan secara umum, dan pembangunan ekonomi pada khususnya (Pinto, 1994). UNDP (1994) menjelaskan governance is defined as the exercuse of political, economic, and aminisrative authority to manage nation's affair at all level. Governance has legs; economic, political and administrative. Pandangan ini menegaskan bahwa governance mempunyai tiga dimensi yakni dimensi politik, ekonomi dan dimensi administrasi, dimana ketiga dimensi tersebut berpengaruh terhadap pembuatan dan pelaksanaan kebijakan pemerintah (negara). Karena itu, sistem pemerintahan good governance mencakup proses dan struktur masyarakat yang mengarahkan hubungan-hubungan sosial ekonomi dan politik untuk menciptakan kehidupan yang lebih baik.

Pengertian good dalam konteks good governance mengandung dua pengertian (Widodo, 2000), Pertama, good berarti nilainilai yang menjunjung tinggi kehendak rakyat dan nilai-nilai yang dapat meningkatkan kemampuan rakyat dalam pencapaian kemandirian, pembangunan berkelanjutan dan keadilan sosial, dengan orientasi pada demokratisasi dalam kehidupan bernegara, dan mengedepankan legitimacy, accountability, authonomy dan devolution of power. Kedua, aspek-aspek fungsional dari pemerintahan yang efektif dan efisien dalam melaksanakan tujuan nasional dengan orientasi pada bagaimana pemerintahan mempunyai kompetensi serta struktur dan mekanisme politik dan administrasi berfungsi secara efisien dan efektif.

Berkaitan dengan orientasi good governance, Masdiasmo (2002) orientasi pembangunan sektor publik adalah untuk menciptakan good governance, dimana pengertian dasarnya adalah kepemerintahan yang baik, yang berupaya menciptakan penyelenggaraan manajemen pembangunan yang solid dan bertanggung jawab sesuai dengan prinsip demokrasi, efisiensi, pencegahan korupsi, baik secara politik maupun administratif. Good governance menuntut reformasi peran aparatur negara agar mampu mendukung kelancaran dan keterpaduan pelaksanaan tugas dan fungsi penyelenggaraan pemerintahan dan pembangunan.

Di Indonesia, reformasi sistem pemerintahan dan pelayanan publik yang ditandai dengan lahirnya berbagai ketentuan yang berkaitan dengan penyelenggaraan sistem pemerintahan negara/daerah berdasarkan paradigma good governance yakni suatu sistem pemerintahan yang lebih transparans, berkeadilan, akuntabel dengan mengedepankan pelayanan publik.

Tujuan reformasi sistem penyelenggaraan birokrasi pemerintahan dalam rangka penguatan dan pemberdayaan peran serta masyarakat dalam berbagai aktivitas pemerintahan, termasuk dalam pengambilan kebijakan publik. Ide dasar reformasi sistem pemerintahan birokrasi adalah negara sebagi institusi legal formal dan konstitusional yang bertugas menyelenggarakan pemerintahan, baik dalam fungsinya sebagai regulator maupun sebagai agent of changes. Reformasi sistem pemerintahan menuntut adanya implementasi yang sebenarnya dari civil society, yakni sistem pemerintahan yang memberi ruang gerak yang luas bagi masyarakat untuk turut serta berperan dalam penyelenggaraan pemerintahan negara/daerah dan implementasi dari sistem pemerintahan yang demokratis yang menjadi inti dari good governance.

Suatu negara dengan kondisi heterogenitas yang tinggi dalam berbagai hal seperti etnis, budaya, geografis, agama, dan tingkat perkembangan sosial-ekonomi, merupakan potensi yang cukup besar sebagai sumber konflik, dan dapat mengarah pada disintegrasi bangsa. Potensi konflik makin besar ketika pemerintah mengembangkan sentralisasi sistem pemerintahan, politik dan ekonomi, di mana pengambilan keputusan dilakukan secara terpusat (sentralistik) sehingga sering menimbulkan kekecewaan masyarakat daerah. Kondisi tersebut makin memperkuat proposisi bahwa pengembangan masyarakat madani dengan sistem pemerintahan desentralisti dan demokratis adalah suatu keniscayaan. Masyarakat madani memerlukan bukan hanya untuk mempertahankan 
kelangsungan kehidupan sosial dan politik masyarakat yang mandiri dan demokratis, tetapi juga untuk kelangsungan pemerintahan itu sendiri.

Dalam konteks sistem pemerintahan dan sistem politik tersebut, maka pertanyaan yang perlu dijawab adalah; apa yang harus dilakukan untuk mendorong pengembangan masyarakat madani di Indonesia?. Format sistem pemerintahan yang bagaimana yang seharusnya dikembangkan agar mampu memfasilitasi pengembangan masyarakat madani?.

Sistem birokrasi seperti apa yang kondusif bagi pengembangan masyarakat madani. Pengembangan masyarakat madani memerlukan ruang publik (public sphere) di mana setiap warga negara bisa secara bebas dan mandiri mengemukakan pendapatnya tentang berbagai masalah kemasyarakatan. Masyarakat seharusnya memiliki ruang gerak yang memadai untuk memanfaatkan potensinya dalam pemenuhan kebutuhan hidupnya, seperti kebebasan menentukan arah/pilihan politik, perlakuan yang adil secara hukum, biaya dan pelayanan pendidikan dan kesahatan yang murah, serta kebutuhan lainnya. Konsep masyarakat madani bermuara pada tiga syarat pokok dalam pemerintahan yaitu: 1) kompetisi yang sesungguhnya dan di anrtara individu dan kelompok, tidak ada unsur paksaan, 2) partisipasi politik yang melibatkan sebanyak mungkin warga negara dalam pembuatan kebijakan publik, 3) kebebasan politik dalam seluruh proses sosial dan kenegaraan.

\section{TRANSPARANSI SEBAGI PILAR REFORMASI PELAYANAN PUBLIK}

Konsep dan penggunaan istilah transparansi dewasa ini makin populer sejalan dengan perkembangan peradaban manusia yang menuntut agar penyelenggaraan pemerintahan menganut asas keterbukaan dan transparansi. Pemerintahan yang tidak mengedepankan keterbukaan dan transparansi saat ini dianggap sebagai bukanlah sistem pemerintahan baik dan ideal. Transparansi dalam penyelenggaraan sistem pemerintahan, khususnya pelayanan publik merupakan salah satu ciri utama good governance. Karena good governance menayaratkan adanya transparansi dalam seluruh aspek yang berkaitan dengan penyelenggaraan pemerintahan dan pelayanan publik. Transparansi dimulai dari proses perencanaan, implementasi sampai dengan evaluasi.

Informasi yang melatarbelakangi setiap tindakan pemerintah, seperti bentuk tindakan, waktu, proses, biaya, dan aktornya harus di publikasikan kepada masyarakat sebagai implememtasi dari accountability kepada publik. Masyarakat diberi akses yang luas untuk mendapatkan seluruh informasi yang dibutuhkan terkait dengan penyelenggaraan sistem pemerintahan. Organisasi pemerintahan tidak boleh menutup akses informasi bagi masyarakat yang membutuhkan informasi. Karena melalui keterbukaan informasi tersebut masyarakat dapat menilai arah, tujuan, proses, implementasi dan hasil-hasil yang dicapai organisasi publik dalam menjalankan fungsinya sebagai pelayan masyarakat. Melalui keterbukaan informasi masyarakat dapat melakukan kontrol, menentukan sikap dan merespons atas penyelenggaraan sistem pemeritahan dan pelayanan publik. Melalui keterbukaan informasi, masyarakat dan seluruh stakeholders dapat mengetahui proses perencanaan, implementasi kebijakan yang disusun bersama oleh masyarakat dan pemerintah.

Masyarakat perlu mengetahui apakah anggaran yang tersedia telah digunakan sesuai dengan kinerja yang diharapkan? Apakah kebijakan yang dibuat telah dilaksanakan dengan baik?. Hal ini semua hanya mungkin diketahui jika pemerintah mengembangkan keterbukaan informasi, dan terjadinya komunikasi dua arah dalam penyelenggaraan pemerintahan. Pemerintahan good governace menuntut pemerintah mendengar suara publik, tidak boleh berpurapura tidak mendengar dan tidak mengetahui suara publik. Bahkan sangat dituntut agar pemerintah segera memberi respons jika ada tuntutan dan keinginan masyarakat yang memang sejalan dengan tujuan dan sasaran penyelenggaraan pemerintahan dan pelayanan publik. 
Pada negara-negara maju yang mengembangkan sistem pemerintahan demokratis, pemerintah menjamin adanya akses bagi masyarakat untuk mengetahui informasi mengenai dinamika kegiatan pemerintahan. Masyarakat memiliki the right to know terhadap apa pun yang terjadi dalam organisasi pemerintahan. Masyarakat dijamin hakhaknya untuk mengetahui perkembangan kegiatan yang sedang dan akan berlangsung. Hal ini semua dimaksudkan agar selain agar masyarakat dapat mengetahui mengenai aktivitas pemerintah, juga agar masyarakat dapat memberikan masukan kepada pemerintah jika memang diperlukan. Masyarakat adalah pengguna hasil kerja pemerintahan, karena itu masyarakat berkewajiban memberi saran dan masukan kepada pemerintah jika mereka melihat bahwa ada sesuatu yang tidak sejalan dengan kebutuhan dan tuntutan masyarakat. Setiap aparatur birokrasi pemerintahan berkewajiban menjelaskan kepada masyarakat mengenai aktivitas pemerintahan baik diminta maupun tidak diminta oleh masyarakat.

Namun dalam banyak hal, keterbukaan sistem pemerintahan di Indonesia masih belum sepenuhnya menjalankan prinsip-prinsip keterbukaan informasi pelayanan publik. Masih terdapat organisasi publik yang hanya menyampaikan hal-hal yang bersifat umum seperti kebijakan dan proses penyelenggaraan kebijakan operasional yang bersifat teknis, tetapi kurang terbuka mengenai halhal yang sensitif, seperti informasi keuangan, baik sumbernya maupun penggunaannya. Ketertutuan infomasi dan komunikasi publik, tidak hanya berlaku bagi orang-orang diluar ogranisasi publik atau masyarakat, tetapi juga sering dilakukan terhadap anggota organisasi lainnya didalam organisasi tersebut, baik pejabat pada bidang yang berbeda maupun stafnya sendiri.

Biasanya yang mengetahui hal-hal yang berkaitan dengan anggaran suatu proyek untuk kepentingan publik hanya orang-orang tertentu, seperti pimpinan beserta staf yang secara hirarkis bertanggung jawab atas pelaksanaan proyek tersebut, sementara rekan kerja yang berbeda bidang tugasnya tidak mendapatkan informasi yang memadai mengenai hal tersebut walaupun mereka berada dalam institusi yang sama. Kondisi seperti ini memperlihatkan betapa rendahnya kualitas transparansi informasi yang masih berlangsung pada berbagai organisasi publik. Sudah menjadi tradisi dan pemandangan umum diberbagai organisasi publik di Indonesia, dimana informasi tentang hal-hal yang berkaitan dengan penyelengggaraan pelayanan publik, khususnya mengenai hal-hal yang sensitif seperti anggaran masih sangat sulit didapatkan. Karena itu, transparansi informasi pelayanan publik masih merupakan sesuatu yang menjadi tantangan dalam mewujudkan penyelenggaraan pelayanan publik. Bahkan ada kecenderungan bahwa informasi mengenai hal-hal yang sensitif tersebut menjadi barang mewah dan langka sehingga tidak mungkin dikonsumsi oleh masyarakat luas.

Ketertutupan informasi pelayanan publik yang demikian itu mengindikasikan bahwa untuk mewjudkan good governance melalui transparansi pelayanan publik masih merupakan kendala dan tantangan yang menuntut kebijakan dan kemauan politik (political will) pemerintah yang sungguh-sungguh jika konsisten dan komitmen terhadap penyelenggaraaan ketatapemerintahan yang baik (good governance). Keterbukaan atau transparansi informasi dan penyelenggaraan pelayanan publik merupakan tuntutan pokok dalam penyelenggaraan pemerintahan yang menganut prinsip good governance, dimana didalamnya diharuskan adanya keterbukaan informasi sebagai salah satu persyaratan implementasi dari akuntabilitas publik.

Transparansi pelayanan publik, tidak hanya bekaitan dengan kebijakan (policy), tetapi juga menyangkut seluruh aspek penyelenggaraan pelayanan publik, mulai dari proses munculnya gagasan, perencanaan, implementasi, pengendalian, dan evaluasi seharusnya dilakukan secara transparan. Dalam melakukan semua ini seharusnya melibatkan seluruh stakeholders yakni masyarakat, swasta dan pemerintah secara bersama-sama memikirkan dan merumuskan seluruh aspek yang berkaitan dengan ide, gagasan, penyelenggaraan, dan pengendalian pelayanan publik yang dilakukan oleh pemerintah. 
Dalam realitasnya, masyarakat sering tidak memiliki akses yang cukup untuk mendapatkan informasi yang komprehensif mengenai berbagai hal yang berkaitan dengan pelayanan publik. Warga masyarakat kurang memiliki informasi yang komprehensif mengenai prosedur dan proses pelayanan publik yang seharusnya dilakukan. Bahkan sebagian besar masyarakat tidak mengetahui persis apa yang menjadi hak dan kewajibannya.

Masyarakat cenderung lebih banyak mengetahui kewajiban daripada haknya, sebab organisasi publik memang lebih mengedepankan informasi tentang kewajiban masyarakat atas pelayanan publik yang diberikan daripada haknya. Sehingga ketika berhadapan dengan organisasi publik (birokrat), masyarakat mengikuti apa saja yang dianjurkan-diperintahkan oleh birokrat. Kondisi pelayanan semacam ini sangat bertentangan pradigma good governance yang mengutamakan keterbukaan atau transparansi baik mekanisme, biaya, tempat, waktu dan petugas pelayanan serta kesetaraan antara birokrat dengan warga masyarakat, maupun keseimbangan antara hak dan kewajiban warga masyarakat dan pemerintah (birokrasi).

Proses dan prosedur pelayanan yang panjang, berbelit-belit dan rumit tentu saja menciptakan opportunity cost yang besar, waktu pengurusan yang panjang dan tenaga yang melelahkan bagi pengguna layanan publik. Kondisi seperti ini mendorong masyarakat mencari cara mudah serta jalan pintas untuk menyiasati bagaimana cara menerima pelayanan publik yang cepat, yang tidak banyak membuang waktu dan energi walaupun dengan risiko biaya yang lebih tinggi. Praktek semacam ini sangat lazim dan mudah dijumpai dalam proses penyelenggaraan publik pada beberapa instansi pemerintahan. Bahkan prakrek semacam ini sudah cenderung dianggap sebagai hal yang wajar dan menguntungkan semua pihak, baik penerima maupun pemberi layanan publik. Praktek semacam ini sejalan dengan temuan GDS 2002 yang menunjukkan bahwa kebanyakan para pengguna jasa pelayanan publik justru merasa lega dan terbantu ketika diminta membayar pungutan diluar ketentuan yang berlaku (pungutan liar), yang penting urusan cepat selesai. Sebagian lagi menganggap pungutan liar sebagai hal yang wajar dan tidak berkeberatan membayarnya.

Anggapan yang demikian ini muncul karena para pengguna jasa layanan publik sudah terlalu lama dan sering membayar pungli, sehingga perilaku seperti ini sudah dianggap hal yang biasa dan tidak lagi dinilai sebagai hal yang menyimpang dan memberatkan. Pengguna jasa ketika ingin berhadapan dengan birokrasi publik mereka telah mengetahuainya dan telah mempersiapkan diri melakukannya. Sebagian tidak berpikir apakah perilaku ini sesuai atau tidak sesuai dengan ketentuan yang berlaku. Bahkan bagi mereka yang mengetahui pun juga melakukan hal yang sama karena mereka telah memahami bahwa sudah jarang sekali mengurus pelayanan publik yang tidak menggunakan biaya tambahan diluar ketentuan yang berlaku. Namun demikian, jika hal ini dibiarkan berlangsung tanpa adanya upaya sungguhsungguh untuk menjalankan transparansi dan akuntabilitas dalam pelayanan publik maka tentu saja sangat sulit untuk mewujudkan clean and good governance melalui transparansi pelayanan publik.

Reaksi masyarakat pengguna jasa layanan publik ketika dimintai uang rokok oleh birokrat adalah: (1) Masyarakat pengguna jasa layanan publik yang menganggap uang rokok (pungli) sebagai hal yang wajar tetapi tidak mau membayar di desa dan dikota ratarata $4,7 \%$. (2) Yang marah dan menolak membayar rata-rata 13,9 \%, (3) Yang merasa lega karena dengan demikian urusan cepat selesai rata-rata 15,5\%, (4) Yang merasa keberatan tetapi tetap membayar rata-rata 19,9\%, (5) Yang menganggap pungli sebagai hal wajar sehingga rela membayarnya ratarata $46,1 \%$.

Temuan di atas mengindikasikan bahwa persoalan pungutan liar dalam proses pelayanan publik telah merupakan suatu hal yang cukup memperihatinkan, dimana pengguna jasa pelayanan publik jauh lebih besar yang menganggap pungutan liar dalam pelayanan publik sudah merupakan tradisi yang berlangsung cukup lama dan merambah keseluruh 
aspek pelayanan publik. Tentu saja hal ini sangat bertentangan dan jauh dari prinsipprinsip good governance yang telah lama dipraktekkan di negara-negara maju. Dan perilaku semacam ini pulalah yang menjadi hambatan utama dalam upaya mewujudkan good governance di Indonesia.

Ketidakseimbangan antara hak dan kewajiban masyarakat dengan birokrasi mengindikasikan beberapa hal: Pertama, kondisi ini menunjukkan betapa lemahnya posisi tawar masyarakat dihadapan pemerintah. Di sini nampak kekuasaan pemerintah terlalu kuat dan sebaliknya posisi masyarakat sangat lemah. Pemerintah dapat mendiktekan keinginannya dalam proses penyelenggaraan pelayanan publik. Pemerintah dapat menuntut atau mewajibkan masyarakat melakukan banyak hal untuk mendapatkan pelayanan dari birokrasi, namun pada saat yang sama hakhak masyarakat kurang mendapat perhatian. Kondisi seperti ini mermunjukkan masih berlangsungnya pemerintahan yang bad governance.

Kedua, Ketidakseimbangan antara hak dan kewajiban yang sering ditemukan dalam penyelenggaraan pelayanan publik menunjukkan inkonsistensi birokrasi dalam mewujudkan transparansi. Birokrat berdalih bahwa trasparansi birokrasi telah berlangsung ketika prosedur pelayanan telah dipajang dipapan pengumuman atau melalui media massa, padahal yang diumumkan itu adalah hal-hal yang berkaitan dengan kewajiban termasuk sanksi bagi pengguna jasa layanan, yang tidak mentaati prosedur dan ketentuan dalam pelayanan publik, sementara yang berkaitan dengan hak-haknya jarang sekali diumumkan. Demikian juga kewajiban penyelenggara layanan jarang diumumkan termasuk sanksi yang diterima jika layanan publik yang diberikan kepada masyarakat tidak sesuai dengan ketentuan yang berlaku. Suatu hal yang perlu dijelaskan bahwa dalam rangka penyelenggaraan pelayanan publik yang sessuai dengan pradigma good governance adalah kharusan adanya keseimbangan antara hak dan kewajiban antara masyarakat pengguna jasa pelayanan dengan birokrasi penyelenggara pelayanan.
Konsep transparansi sering digunakan secara tumpang tindih dengan paradigma lain dalam good governance seperti accountability dan responsiveness. Konsep transparansi menunjuk pada suatu keadaan dimana segala aspek dari proses penyelenggaraan pelayanan publik dilaksanakan secara terbuka (bersifat terbuka) dan dapat diketahui dengan mudah oleh para stakeholders. Dimensi-dimensi pelayanan publik yang seharusnya dilakukan secara terbuka seperti persyaratan, biaya, waktu, tempat, waktu dan personnel (Waluyo, 2005), serta hak dan kewajiban penyelenggara (birokrasi) seluruhnya dipublikasikan secara terbuka sehingga mudah diakses bagi mereka yang membutuhkan.

Karena itu, setidaknya ada tiga indikator yang dapat digunakan untuk mengukur transparansi pelayanan publik. Pertama, tingkat keterbukaan proses penyelenggaraan pelayanan publik yang mencakup persyaratan, biaya, waktu yang dibutuhkan dan mekanisme yang harus dipenuhi. Hal ini dimaksudkan agar seluruh stakeholders mengetahui dan mempersiapkan diri untuk melakukan pelayanan publik. Kedua, seberapa mudah peraturan pelayanan dipahami oleh masyarakat dan stakeholders lainnya. Maksud dari "memahami" bukan hanya dalam artilateral tetapi juga makna dibalik semua peraturan tersebut. Diperlukan penjelasan mengenai persyaratan, biaya, prosedur dan batas waktu setiap jenis pelayanan publik. Jika semua hal ini diketahui secara jelas oleh masyarakat, maka diharapkan akan terjadinya kepatuhan dalam melakukan pelayanan publik. Publikasi informasi mengenai berbagai aspek pelayanan publik tersebut menjadikan masyarakat tidak lagi banyak bertanya mengenai apa yang harus dilakukan dalam pelaksanaan suatu jenis pelayanan publik. Hal ini penting, karena setiap jenis pelayanan publik memiliki standar pelayanan tersendiri dalam hal biaya, waktu, tempat, prosedur serta personnel penyelenggaraan pelayanan publik.

Transparansi tidak hanya berkaitan dengan kelancaran penyelenggaraan pelayanan publik, tetapi juga berkaitan dengan kepercayaan, dan menghilangkan kecurigaan yang memang sudah lama mendera birokrasi 
di Indonesia. Dewasa ini telah terjadi kecurigaan dalam berbagai aspek kehidupan dan aktivitas pelayanan publik, terutama pelayanan publik yang dilaksanakan oleh birokrasi pemerintahan. Kecurigaan ini berawal dari berbagai pengalaman masyarakat ketika berhubungan dengan birokrasi publik, baik masa lalu maupun saat ini. Sehingga tidak mengherankan jika masyarakat mempertanyakan setiap kebijakan yang berkaitan dengan pelayanan publik, terutama masalah biaya yang sebenarnya diperlukan untuk suatu jenis pelayanan publik. Ketiga, kemudahan memperoleh informasi yang benar mengenai aspek-aspek yang berkaitan dengan penyelenggaraan pelayanan publik.

Sering terjadi, dimana informasi diterima oleh masyarakat berbeda dengan kebijakan yang sebenarnya. Lain yang diputuskan lain pula yang disampaikan. Untuk menghindari hal-hal yang demikian atau miskomunikasi, maka diperlukan informasi yang benar-benar valid sehingga masyarakat menaruh kepercayaan kepada birokrasi pemerintahan. Agak sulit mempercayai suatu informasi jika komunikatornya tidak dipercaya. Karena itu, komunikator yang baik adalah mereka yang mampu menyampaikan apa yang sebenarnya menjadi keputusan organisasi.

\section{PENUTUP}

Ketatapemerintahan yang baik (good governance) merupakan suatu peadaban baru yang menjadi paradigma sistem pemerintahan yang mengedepankan pelayanan publik yang berkualitas, dimana didalamnya birokrasi dituntut tidak saja berperan sebagai administrator, komunikator (katalik), tetapi juga sebagai pelayan publik yang diharpkan mampu menciptakan pelayanan yang berorientasi pada customer satisfaction yakni birokrasi yang mampu memberikan pelayanan publik yang memuaskan bagi masyarakat. Salah satu dimensi pelayanan publik yang berkualitas yang menjadi tanggung jawab birokrasi adalah transparansi dalam berbagai aspek pelayanan publik.

Pelayanan publik yang berkualitas merupakan tuntutan dan kebutuhan masyarakat yang tidak dapat diabaikan oleh organisasi pemerintahan. Hal ini menjadi penting dipahami, karena masih ada birokrat yang masih belum sungguh-sungguh mengutamakan pelayanan publik tersebut dalam menjalankan fungsi pemerintahan. Pelayanan publik yang berkualitas harus memenuhi syarat seperti tangibility, reliable, responsiveness, assurance, dan empathy. Jadi pelayanan publik yang dikehendaki dalam good governnce adalah pelayanan publik yang memiliki standar tertentu, bukan pelayanan publik seperti masa lalu yakni pelayanan publik yang lamban, biaya tinggi, berbelit-belit, waktu yang lama serta ditandai dengan korupsi, kolusi dan nepotisme (KKN).

\section{DAFTAR PUSTAKA}

Colebatch, H.K, 2009, "Governance As A Conceptual Development In The Analysis Of Policy" Critical Policy Studies, Vol. 3, No. 1, April 2009, (pp 58-67)

Denhart, Janet V and Robert B. Denhard, 2003. New Public Service: Serving Not Steering. London : M.E. Sharpe.

Dwiyanto, Agus .2002. Reformasi Birokrasi Publik Indonesia. Yogyakarta : PSKK UGM

Frederickson, H. George, 1984. Administrasi Negara Baru (New Publivc Administration), diterjemahkan oleh Al Ghoze, Jakarta : LP3ES.

Hutter, Bridget $\mathrm{M}$ and Jones, Clive J, 2007, "From Government To Governance: External Influences On Business Risk Management" Regulation \& Governance (2007) 1, (pp 27-45)

Keban. Y.T. 2008. Enam Dimensi Stratetgis Administrasi Publik. Yogyakarta: Gava Media.

Kettl. D.F. 2002. The Transformation of Governance. Baltimore and London : The John Hopkins University Press. 
Kristiadi, J.B., 1998. Penyelenggaraan Pemerintahan Daerah dalam Usaha Meningkatkan Pelayanan Publik pada Abad XXI, Bandung, FISIP-UNPAD.

Kumorotomo, Wahyudi, 1994. Etika Administrasi Negara. Jakarta : PT. Grafindo Persada.

Osborne, David and Ted Gaebler, 1996. Reinventing Government (Mewirausahakan Birokrasi), Jakarta : PPM.

Osborne David And Peter Plastrik, 2000. Memangkas Birokrasi. Lima Strategi Menuju Pemerintahan Wirausaha, Jakarta : PPM.
Rakhmat, 2009. Teori Administrasi dan Manajemen Publik. Tangerang : Pustaka Arif

Sarundajang. 2005. Babak Baru Sistem Pemerintahan Daerah. Jakarta : Kata Hasta Pustaka

Waluyo. 2007. Manajemen Publik; Konsep, Aplikasi dan Implementasinya Dalam Pelaksanaan Otonomi Daerah, Jakarta : Mandar Maju.

Zeithaml, V.A. Parasuraman dan L.L.Berry. 1990. Delivering Quality Services Balancing Customer Perception and Expectation, New York : The Free Press 
Vol. I, No. 2, Oktober 2011 